УДК 378.091.212:78.071.2

DOI:

Марина Білецька, кандидат педагогічних наук, дочент, завідувач кафедри інструментального виконавства та музичного мистецтвва естради Мелітопольського державного педагогічного університету імені Богдана Хмельницького

Тетяна Підварко, старший викладач кафедри інструментального виконавства та музичного мистецтвва естради Мелітопольського державного педагогічного університету імені Богдана Хмельницького

\title{
ФОРМУВАННЯ ГОТОВНОСТІ МАЙБУТНЬОГО ВЧИТЕЛЯ МУЗИЧНОГО МИСТЕЦТВА ДО КОНЦЕРТНО-ВИКОНАВСЬКОӤ ДІЯЛЬНОСТІ
}

У статті на основі аналізу науково-методичної літератури розкрито сутність та особливості формування готовності до концертно-виконавської діяльності майбутнього вчителя музичного мистецтва. Участь у концертно-виконавській діяльності сприяє формуванню професійної майстерності студентів, артистизму, адаптації до майбутньої конщертної діяльності, формує творчу активність і самостійність 6 навчанні, зацікавленість музично-професійною діяльністю, підвищує мотивачію до занять, забезпечуе формування практичних навичок $і$ закріплення теоретичних знань.

Ключові слова: музично-виконавська діяльність; емоційний стрес; сиенічний досвід; творча самостійність.

Jim. 10.

Maryna Biletska, Ph.D.(Pedagogy), Associate Professor, Head of the Instrumental Performance and Variety Arts Department Melitopol Bohdan Khmelnytskiy State Pedagogical University

Tetyana Pidvarko, Senior Lecturer of the Instrumental Performance and Variety Arts Department Melitopol Bohdan Khmelnytskiy State Pedagogical University

\section{FORMING OF READINESS OF FUTURE TEACHER OF MUSICALART TO CARRYING THE CONCERT-ACTIVITY}

In the article on the basis of analysis of scientifically-methodical literature the essence and features of forming of readiness are exposed to carrying the concert activity of future teacher of musical art. Participating in carrying the concert activity assists the formation of professional mastery of students, artistry, adaptation to future concerto activity, forms creative activity and independence in studies, personal interest by musically-professional activity, promotes motivation to employments, provides forming of practical skills and fixing the theoretical knowledge.

Process of forming of readiness of future teacher of musical art to concerto-carrying out activity depends direct character on development of creative qualities of personality, from realization of creative displays there are personalities in the process of professional preparation, through that there is becoming and development of creative activity of future specialists.

Carrying the concert activity by students improves the quality of preparation, causes sense of gladness from the process of studies, develops and enriches the emotionally-volitional and intellectual spheres of personality, brings up artistic, musical taste.

The personality-orientated approach exposes the possibilities for independent searches, activates feeling of creative presentation during realization of carrying the concert activity, and sends them to the search of the special, inherent exactly to this student of facilities of self-expression. Feeling of professional possibility becomes soil for successful realization of concert performance. Individualization promotes independence that, in turn, too assists the achievement of successes with professional preparation of student.

Keywords: musical-carrying out activity; an emotional stress; stage experience; creative independence.

$\Pi$ остановка проблеми. Система вищої мистецької освіти перебуває в умовах реформування та вдосконалення. Професійна підготовка майбутнього учителя музичного мистецтва в якості кінцевого результату цього процесу розглядає професійну компетентність як важливе новоутворення особистості, що інтегрує різні якості і властивості 


\section{ФОРМУВАННЯ ГОТОВНОСТІ МАЙБУТНЬОГО ВЧИТЕЛЯ МУЗИЧНОГОМИСТЕЦТВА ДОКОНЦЕРТНО-ВИКОНАВСЬКОЇ ДІЯЛЬНОСТІ}

людини. Тому виникає необхідність активного пошуку нових резервів якісної підготовки фахівців здатних до розвиненого професійного вдосконалення відповідно до вимог конкретної фахової спрямованості.

Метою освітньо-професійної програми підготовки бакалаврів спеціальності 014 “Середня освіта. Музичне мистецтво” є забезпечення умов формування і розвитку загальних та фахових компетентностей для успішного здійснення професійної діяльності вчителя музичного мистецтва у закладах загальної середньої й позашкільної освіти та безперервного особистісно-професійного розвитку впродовж життя. Серед фахових компетентностей, якими повинен оволодіти майбутній вчитель музичного мистецтва, важливе місце посідає здатність до оволодіння вміннями творчої розробки, змістовного наповнення та оформлення позакласних та позашкільних музично-виховних заходів - лекції-концерти, концерти, музичні бесіди, конкурси, музичні квести тощо.

Тому важливо під час формування музичновиконавської компетенції майбутніх учителів музичного мистецтва залучати їх до концертновиконавської діяльності, оскільки це ефективний засіб музично-виконавського і педагогічного становлення майбутнього вчителя.

Аналіз останніх досліджень і публікацій. Наукові праці О. Асмолова, М. Дьяченка, Л. Кандибовича, Г.Кручініна, О. Леонтьєва, В. Моляко, Д. Узнадзе присвячені готовності до діяльності; дослідженню готовності до різних видів педагогічної діяльності приділено увагу в працях Г. Костюка, Ю. Пелеха, В. Сластьоніна, В. Щербини; 3'ясування особливостей підготовки студентів до музично-просвітницької діяльності розкрито в роботах Л. Безбородової, Л. Кожевнікової, С. Куришева, I. Немикіної, I. Полякової; питанням формування культури концертно-виконавської діяльності та поняття культура займалися багато діячів мистецтва Б.В. Асафьев, Г. М. Коган, Б.А. Струве.

Мета статті полягає в розкритті особливостей та специфіки підготовки майбутніх вчителів музичного мистецтва до концертно-виконавської діяльності.

Виклад основного матеріалу. Головна відмінність професійної роботи вчителя музичного мистецтва полягає в тому, що його педагогічна діяльність поєднує функції і викладача, i музиканта-виконавця. Тільки таким чином, взаємодія виконавської і педагогічної діяльності дозволяє забезпечити реалізацію освітньої, виховної, просвітницької та інших функцій музичного мистецтва $[6,4-8]$.
Концертно-виконавська діяльність передбачає глибоке осягнення змісту та вираження власного ставлення до художніх образів у процесі публічної демонстрації, містить потужний потенціал впливу на розвиток особистості, реалізація якого залежить від іiі змісту, способів організації та методичного забезпечення [3, 128 - 134].

Формами реалізації концертно-виконавської діяльності студента, де він виступає на сцені перед публікою, творчо самореалізується, виступають конкурси, фестивалі, концертні виступи на різноманітних заходах.

Іван Касілов зазначає, що спостерігається тенденція до посилення уваги на інструментальновиконавську діяльність в умовах музичнопедагогічної освіти, а також визначення власної концепції інструментально-виконавської діяльності майбутнього вчителя музичного мистецтва, яка характеризується наявністю необхідних професійних знань, умінь та навичок, спрямованих на професійне опанування музичним інструментом та використанням його у процесі професійної підготовки майбутнього вчителя музичного мистецтва, у організаційнопросвітницьких заходах з музичного мистецтва (концерти, фестивалі, конкурси, лекції-концерти, творчі вечори тощо [5, 70 - 76].

Музично-виконавська діяльність вчителя музичного мистецтва в закладі середньої освіти не обмежується проведенням одного тільки заняття. Вчитель нерідко є й організатором i виконавцем концертних програм у позаурочній та позакласній виховній роботі з учнями. Сучасний вчитель музичного мистецтва має володіти всім комплексом інструментальної підготовки, для цього в нього повинні бути сформовані такі спеціальні компетентності як уміння інтерпретації музичного твору, транспонування, підбір акомпанементу, читання нот $з$ листа, здатність демонструвати у процесі музичної діяльності музично-виконавські навички, поєднання інструментально-виконавських, інтерпретаційних, артистичних умінь, виконавської надійності та інше.

Інструментально-виконавська підготовка студентів це двоєдиний поетапний процес, який передбачає навчання грі на музичному інструменті, а також концертно-виконавську діяльність студентів [8].

Процес формування готовності майбутнього вчителя музичного мистецтва до концертновиконавської діяльності безпосереднім чином залежить від розвиненості творчих якостей особистості, від реалізації творчих проявів особистості в процесі професійної підготовки, 


\section{ФОРМУВАННЯ ГОТОВНОСТІМАЙБУТНЬОГО ВЧИТЕЛЯ МУЗИЧНОГО МИСТЕЦТВА ДОКОНЦЕРТНО-ВИКОНАВСЬКОЇ ДІЯЛЬНОСТІ}

через які відбувається процес становлення i розвиток творчої діяльності майбутніх фахівців.

Головним завданням в професійно-практичній підготовці студентів у закладі вищої освіти є формування творчої самостійності, успіх якої можливий лише за умови цілісної єдності професійної підготовки: методів вивчення, професійних і пізнавальних систем знань, здатність до самостійного освоєння, оцінки досягнень.

Музично-виконавська діяльність як певний вид творчої діяльності реалізується в двох формах: духовно-практичній - формування художнього задуму і діяльнісно-практичній - втілення цього задуму в звуках, його обробці і у виконанні музики [9].

Л.І. Гаркуша висвітлює різні форми самостійної роботи студентів у процесі концертновиконавської та педагогічної практики, які сприяють формуванню його педагогічного досвіду. Основною метою концертно-виконавської роботи студентів $€$ формування сценічного досвіду, музично-виконавських навичок і вмінь необхідних для плідної професійно-педагогічної та художньопросвітницької діяльності майбутнього вчителя музичного мистецтва. Основні завдання цієі роботи:

- удосконалення, закріплення та поглиблення практичних виконавських навичок і вмінь, набутих у процесі навчання;

- формування досвіду організації музичнопросвітницької роботи;

- розвиток здатності самостійно мислити, аналітично-критично ставитися до власної професійної діяльності, виховання почуття відповідальності $[1,17]$.

Вибір репертуару і дотримання певних засад складання концертно-виконавських програм одна із умов досягнення їі успішності. Крім того, принципово актуальним для досягнення просвітницького ефекту концертних виступів набувають такі аспекти, як намагання встановити контакт зі слухацькою аудиторією, здатність до акцентування індивідуальної самобутності творчої особистості виконавця в нерозривній єдності 3 його прагненням до глибокого проникнення і відтворення стильових ознак музики, їі духовної суті; використання звукотворчої енергетики митця, потужності його художньовольового посилу; артистизм, опора на зворотню реакцію слухачів, що є стимулом сценічного натхнення $[2,17]$.

Дуже важливо, вказує Н.А. Калугіна, щоб система психолого-педагогічної підготовки учителя будувалася на основі наступних положень:

- міжособистісна взаємодія педагога i студента має вибудовуватися на основі формування у майбутніх музикантів позитивного самоставлення, довіри до його особистості, його можливостям, віри в його сили;

- будь-яка діяльність (на лекціях, семінарах, практичних заняттях, тренінгах) повинна спиратися на мотивацію діяльності, щоб особистісне керівництво самопізнання і пізнання у студентів визначалося на основі сформованих смислів, рефлексивного усвідомлення важливості і значущості для себе;

- основою професійної діяльності студенамузиканта слід визнати вольову саморегуляцію, висхідну до самоврядування особистості; локус контролю в цьому випадку знаходиться в свідомості особистості $[4,25]$.

До принципів готовності майбутнього вчителя музичного мистецтва до концертно-виконавської діяльності відносимо:

- єдність художнього і технічного розвитку;

- поступовість і послідовність в оволодінні виконавською майстерністю;

- особистісно зорієнтований підхід до студента;

- креативність.

Рівень сформованості до концертновиконавської діяльності визначається за показники: сформованість музично-виконавських навичок, вміння вести себе на сцені, уміння долати емоційний стрес (концертне хвилювання). Емоційний стрес-це зовнішній вплив на суб' єктів, який, незалежно від своїх різноманітних особливостей, викликає комплекс негативних емоцій, що знижують оперативні можливості короткочасної пам'яті або прямо чи побічно послаблюють загальний опір організму. На думку Л.М.Котової, в період розігрування перед виступом на естраді, з метою надійного виконання музичної інформації студентам-інструменталістам потрібно:

- абсолютно відволікатися від зайвих думок про виступ;

- подумки нівелювати негативну дію передбачених зовнішніх стрес-факторів;

- встановити бажану силу діючої мотивації;

- відтворити раніше знайдений оптимум збудження як для кожного твору, так і для всієї програми;

- нівелювати сприйняття проміжних результатів, а у випадку мимовільного його “зняття" - спрямовувати увагу тільки на вдало відтворену інформацію;

- зберігати психофізіологічну напругу тільки в межах встановленого оптимуму;

- програючи визначений арсенал музичного матеріалу, не змінювати й не піддавати сумніву програму техніко-тактичних дій; 


\section{ФОРМУВАННЯ ГОТОВНОСТІ МАЙБУТНЬОГО ВЧИТЕЛЯ МУЗИЧНОГОМИСТЕЦТВА ДОКОНЦЕРТНО-ВИКОНАВСЬКОЇ ДІЯЛЬНОСТІ}

- без особливих вольових зусиль безупинно рухати думку за процесом гри;

- захоплюватися мікроструктурною побудовою мелодико-ритмічної лінії в гнучкому інтонаційнофразовому розвитку;

- розігратися без перевтоми виконавського апарату;

- на завершальній стадії розігрування (перед виходом на сцену) максимально активізувати переживання емоційно-образного змісту музики першого твору концертної програми;

- виключити з об'єктів уваги власне “Я” [7, $164-165]$.

Також для формування готовності студентів до концертно-виконавської діяльності необхідно застосовувати такі методи:

- уявне “програвання”, без нот, метод який розвиває музично-слухові уявлення, що стає опорою для осмислення фразування і конструкції музичного матеріалу;

- моделювання концертної ситуації, що дозволяє регулювати процес адаптації до оптимального концертного стану, попереднє знайомство з концертним залом, його акустикою, базуючись на широті музичного кругозору спеціаліста, розвинених музично-виконавських умінь, засобів музично-художньої виразності і т.д.

Створення моделі ситуації концертного виступу доцільне лише за умови достатньої готовності програми, в такому випадку виконання програми здійснюється цілком і в повну силу. Облік стрес-фактора передбачає наявність стресора, де в ролі останнього можуть виступати люди, що знаходяться на репетиції, диктофон, відповідна установка виконавця. Облік сценічності містить забезпечення відповідного зовнішнього вигляду артиста, слухачів, виконання необхідних сценічних рухів музикантом-виконавцем [10].

Отже, участь у концертних виступах - це показ кінцевого результату роботи над музичними творами (програмою), метою якого є розкриття музично-художнього задуму музичних творів та виявлення загального виконавського рівня та професійної підготовки студентів.

Висновки і перспективами подальших наукових розвідок. Концертно-виконавська діяльність активізує у студентів творчий потенціал сприяючи зростанню творчої індивідуальності, підвищує якість виконавської підготовки, викликає почуття радості від процесу навчання, розвиває і збагачує емоційно-вольову та інтелектуальну сфери особистості, виховує артистичність, музичний смак.

Подальше дослідження означеної проблеми передбачає пошук інших форм, методів, прийомів формування готовності майбутнього вчителя музичного мистецтва до концертно-виконавської діяльності.

\section{ЛІТЕРАТУРА}

1. Гаркуша Л.І. Самостійна робота майбутнього вчителя музичного мистецтва у процесі концертновиконавської та педагогічної практики. Музичне мистецтво в освітньому дискурсі. 2016. №1. С. 89-93.

2. Жигінас Т.В. Методика підготовки майбутніх учителів музики до концертно-освітньої діяльності. Київ, 2014. С.17

3. Заїка О.Я. Формування потреби в концертновиконавській діяльності як умова розвитку художньо-творчих здібностей майбутніх педагогів. Вісник Глухівського національного педагогічного університету імені Олександра Довженка. Серія: Педагогічні науки, 2016. Вип. 32. C.128-134.

4. Калугина Н.А. Роль и место психологопедагогической подготовки при личностном становлении будущего специалиста (на примере профессионального образования учителямузыканта в вузах искусств и культуры). История и культура Приамурья, 2008. № 1(3). С. 25

5. Касілов I. Специфіка професійної підготовки майбутніх учителів музичного мистецтва до інструментально-виконавської діяльності. Педагогічний процес: теорія і практика (серія: педагогіка). Київ, 2017. № 2 (57). С.70-76.

6. Косінська Н.Л. Сутнісна характеристика сценічно-образної культури майбутніх вчителів музичного мистецтва в процесі вокальної підготовки. Science Rise: Pedagogical Education, 2017. № 10. C. 4-8.

7. Котова Л.М. Методика підготовки музикантів-інструменталістів до сценічної діяльності: навчально-методичний посібник. 2-ге видання, перероблене. Мелітополь, 2014. С.164165

8. Лантух Т.В. Совершенствованиеинструментально исполнительской подготовки будущих учителей музыки. Подготовка компетентного специалиста в образовательном пространстве учреждения образования. URL: https://elib.grsu.by/katalog/ 162374-349944.pdf (дата звернення: 10.11.2019)

9. Самсонова О. В. К вопросу о творческой деятельности будущего учителя музыки. Психология образования в поликультурном пространстве, 2010. №2. C.119-123. URL: https:// cyberleninka.ru/article/v/k-voprosu-o-tvorcheskoydeyatelnosti-buduschego-uchitelya-muzyki (дата звернення: 11.11.2019)

10. Цагарелли Ю.А. Психология музыкально- 
исполнительской деятельности. Санкт-Петербург, $2008,368 \mathrm{c}$.

\section{REFERENCES}

1. Harkusha, L.I. (2016). Samostiina robota maibutnoho vchytelia muzychnoho mystetstva $\mathrm{u}$ protsesi kontsertno-vykonavskoi ta pedahohichnoi praktyky [Independent work of future teacher of musical art is in the process of concerto-carrying out and pedagogical practice]. A musical art is in educational discourse. No.1, pp. 89-93. [in Ukrainian].

2. Zhyhinas, T.V. (2014). Metodyka pidhotovky maibutnikh uchyteliv muzyky do kontsertnoosvitnoi diialnosti [Methodology of preparation of future music masters is to concerto-educational activity]. Kyiv, 178 p. [in Ukrainian].

3. Zaika, O.Ia. (2016). Formuvannia potreby v kontsertno-vykonavskii diialnosti yak umova rozvytku khudozhno-tvorchykh zdibnostei maibutnikh pedahohiv [Forming of requirement in concertocarrying out activity as a condition of developing artistically-creative flairs of future teachers]. Bulletin of Oleksandr Dovzhenko Hlukhiv national pedagogical university. Series: Pedagogical sciences. Vol.32. pp. 128-134. [in Ukrainian].

4. Kalugina, N.A. (2008). Rol i mesto psikhologopedagogicheskoy podgotovki pri lichnostnom stanovlenii budushchego spetsialista (na primere professionalnogo obrazovaniya uchitelya-muzykanta $\mathrm{v}$ vuzakh iskusstv i kultury) [Role and place of psychological and pedagogical preparation at the personality becoming of future specialist (on the example of trade education of teacher-musician in institutions of higher learning of arts and culture)]. History and culture of Priamurya. No. 1(3). p.25. [in Russian].

5. Kasilov, I. (2017). Spetsyfika profesiinoi pidhotovky maibutnikh uchyteliv muzychnoho mystetstva do instrumentalno-vykonavskoi diialnosti
[A specific of professional preparation of future teachers of musical art is to instrumental-carrying out activity]. Pedagogical process: theory and practice (series: pedagogics). Kyiv, 2 (57). pp. 70 76. [in Ukrainian].

6. Kosinska, N.L. (2017). Sutnisna kharakterystyka stsenichno-obraznoi kultury maibutnikh vchyteliv muzychnoho mystetstva $\mathrm{v}$ protsesi vokalnoi pidhotovky [Essence description of stage-vivid culture of future teachers of musical art is in the process of vocal preparation]. Science Rise: Pedagogical Education. No.10. pp. 4-8. [in Ukrainian].

7. Kotova, L.M. (2014). Metodyka pidhotovky muzykantiv-instrumentalistiv do stsenichnoi diialnosti: navchalno-metodychnyi posibnyk [Essence description of stage-vivid culture of future teachers of musical art is in the process of vocal preparation: raining manual]. 2-e vyd. Vypr. Melitopol, pp.164-165. [in Ukrainian].

8. Lantukh, T.V. Sovershenstvovanie instrumentalno ispolnitelskoy podgotovki budushchikh uchiteley muzyki [Perfection of instrumental carrying out preparation of future music masters]. Preparation of competent specialist is in educational space of establishment of education. Available at: https://elib.grsu.by/katalog/ 162374-349944.pdf (accessed 10 Nov. 2019). [in Russian].

9. Samsonova, O. V. (2010). K voprosu o tvorcheskoy deyatelnosti budushchego uchitelya muzyki [To the question about creative activity of future music master]. To the question about creative activity of future music master. No.2. pp. 119-123. Available at: https://cyberleninka.ru/article/v/kvoprosu-o-tvorcheskoy-deyatelnosti-buduschegouchitelya-muzyki (accessed 11 Nov.2019). [in Russian].

10. Tsagarelli, Yu.A. (2008). Psikhologiya muzykalno-ispolnitelskoy deyatelnosti [Psychology of musically-carrying out activity]. Publ. Composer, St.Peterburg, 368 p. [in Russian].

Стаття надійшла до редакції 25.11.2019

\section{G58080}

"Музика надихає увесь світ, дарує душі қрила, сприяє польоту, уяві; музика додає життя $і$ веселощі всьому існуючому... Їі можна назвати втіленням всього прекрасного і всього піднесеного".

Tiлатон

давньогрецький мислитель

“ฯим є музика? Можливо попросту небом з нотами замість зіроқ?"

ЛюдвікЄжи Керн

польсъкий письменник

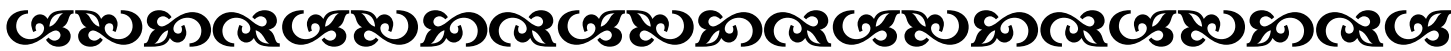

Молодь і ринок №1 (180), 2020 